\title{
A Europe of Creditors and Debtors : Three Orders of Debt Relations in European Integration
}

\section{Losada, Fernando}

2020-07-03

Losada , F 2020 , ' A Europe of Creditors and Debtors : Three Orders of Debt Relations in

European Integration ', Journal of Common Market Studies , vol. 58 , no. 4 , pp. 787-802 . https://doi.org/10.1111/jc

http://hdl.handle.net/10138/335858

https://doi.org/10.1111/jcms.12988

unspecified

acceptedVersion

Downloaded from Helda, University of Helsinki institutional repository.

This is an electronic reprint of the original article.

This reprint may differ from the original in pagination and typographic detail.

Please cite the original version. 
Losada Fernando (Orcid ID: 0000-0001-8546-7563)

Title of the submitted paper: A Europe of creditors and debtors: Three orders of debt relations in European integration

Author: Fernando Losada

Affiliation: Academy of Finland Research Fellow, University of Helsinki

\section{Contact details:}

Faculty of Law - P.O. Box 4

$\mathrm{FI}-00014$, University of Helsinki

Yliopistonkatu 3, Helsinki, Finland

E-mail address: fernando.losada@helsinki.fi

\section{Acknowledgements (to be included):}

This research forms part of the project 'The European Community of Debt: Formation, Institutionalization, Legitimation' funded by the Academy of Finland. Previous versions of this article were presented at the $5^{\text {th }}$ Annual Conference of the Centre of Excellence in Foundations European Law and Polity (University of Helsinki, $19^{\text {th }}$ and $20^{\text {th }}$ September of 2013) and at the workshop 'Community of Debt? The Transnationalisation of Debt and Solidarity in Europe' (European University Institute, $19^{\text {th }}$ and $20^{\text {th }}$ November of 2015). The argumentation has benefited from discussions therein, and in particular from the comments of Adrienne Héritier, Kenneth Dyson, Sabine Frerichs and Agustín José Menéndez. Special thanks to Klaus Tuori for helping to shape the economic argumentation and to the four reviewers, whose detailed comments substantially improved the final result. All errors or oversights remain the author's alone.

This article has been accepted for publication and undergone full peer review but has not been through the copyediting, typesetting, pagination and proofreading process which may lead to differences between this version and the Version of Record. Please cite this article as doi: $10.1111 / \mathrm{jcms} .12988$ 


\section{A Europe of creditors and debtors: Three orders of debt relations in European integration}

\section{Introduction}

'Power is like an iceberg', remaining most of the time below the waterline and 'built into core institutional and organizational structures of societies' (Pierson, 2015, p. 124). Similarly, debt relations between EU Member States, although unnoticed, have existed during more than six decades of European integration (Dyson, 2010, pp. 600-603; Dyson, 2014, pp. 99-126). The division between creditor and debtor states only became evident and its effects a matter of concern after the sovereign debt crisis (Beck, 2013, pp. 43-44; Offe, 2015, pp. 26-27; Fabbrini, 2015; Steinberg and Vermeiren, 2016), but political advantages resulting from debt dynamics have been gradually and stealthily embedded in the institutional architecture of the Union for decades. Consequently, the actual conflict between creditor and debtor Member States can only be properly understood by combining a description of the specific features of international economic relations determining the balance of power between creditor and debtor, with two different but concurrent processes. On the one hand, the changes operated in the European monetary context during a transcendental move from the Bretton Woods system to a single currency, and on the other hand the evolution of the institutional architecture of European integration that has successively consolidated the political advantages obtained by creditors. The conjunction of these two processes has gradually affected the balance between creditor and debtor Member States in the context of European integration.

This article explains how debt relations got entrenched in the EU institutional system. With that objective it reconstructs the interplay between debt relations and the integration process according to three different and cumulative institutional configurations, here referred to as orders of debt relations. With that aim it first concisely explains the primary elements of external debt and the way they interact with the political order in the context of European integration. The following sections then describe each order of debt relations, the first stemming from trade imbalances, the second 
based on the sovereign creditworthiness of Eurozone members and the third resulting from direct debt relations between Member States. In the final section the implications of continual institutionalization of creditor's interests are revealed, rendering explicit the depth of the transformations that European integration has undergone.

\section{Approaching European integration from the perspective of debt relations}

Debt relations are the result of economic events and political struggles that, especially in the context of European integration, have been progressively institutionalized by law as a result of a process in which elements stemming from the three disciplines intervene at different scale at any one time. Reconstructing the history of European integration according to debt relations must therefore link together economic affairs, political agreements and, as final outcomes of that interaction, institutional developments. To be sure, the Union's institutional setting has been gradually established according to a problem-solving rationale, triggering an incremental process causing manifold path-dependencies (Pierson, 1998). The baseline of this article is that juxtaposition of the dynamics of international debt relations with this evolving and increasingly constrained institutional system has occasioned a continuing interplay between the underlying forces inherent to debt relations and those of the political system, ending up structuring and crucially determining (power) relations between Member States.

The result of the interplay between debt relations and the European institutional and political system is here captured in the reconstruction of those interactions according to three orders of debt relations. The distinction between these orders relies on the gradual institutionalization of different types of debt relations, resulting in cumulative constraints over available options that crucially shape the political system of the Union. The narrative proposed through these three orders of debt relations revolves around external debt, understood as the amount owed by a country as a whole to its foreign creditors - combining the net debt of government, companies and households. To a 
considerable extent external debt determines international power relations. Although multiple factors affect its exact configuration and thus the country's correlative position in international power games, external debt stems from three main sources, each source assigning leverage to creditors and debtors through specific mechanisms. External debt may result, in the first place, from cross-border trade, as reflected in the current-account deficit and the consequent structure of the balance of payments. Trade in goods and services establishes interrelations between states that lead to commercial dependencies: the more a state relies on imports (especially for consumption rather than for investment), the greater influence other countries can exert over it. Conversely, a large export sector depends on other countries' consumption. In the medium and long term, asymmetric trade relationships (those between different-sized economies) consolidate the influence of larger over smaller economies (Hirschman, 1945, pp. 18-29; Kirshner, 2006, pp. 149-150). But in the context of European integration, balance of payments determines the leverage of strong over weak currencies, resulting in critical advantages in negotiations about new monetary co-operation (Kaelberer, 2001). A second source of external debt is the amount of sovereign bonds owned by nonresidents. The higher this amount, the more a state is exposed to the influence of external investors and the conditions under which they are willing to purchase its bonds. Hence, in case of urgent need a state can issue either debt expressed in a foreign currency, thus losing the ability to increase the amount of money (inflation) to ease service of the debt, or debt governed by a foreign law, thus renouncing the right to determine the conditions over the debt contract, usually more sensitive to debtor needs (Brunnermeier et al., 2016, p. 126) - or both. The size of the country is not irrelevant in this regard, either. Smaller economies frequently borrow foreign currency 'as a deficit on the government's budget often is accompanied by a trade deficit as well'. In addition, 'the critical debt level at which bondholders lose confidence in a country's ability to pay is lower for small than for large countries' (Hannesson, 2015, p. 9). Finally, external debt may result from obligations contracted with states or international financial institutions as a consequence of loans or reparations. In these cases the state is in a position of disadvantage vis-à-vis its creditors, either 
when negotiating the terms for borrowing money (the more urgent it is, the weaker the position of the state) or, even worse, when reparations are accepted in return for damage resulting from an armed conflict. By contrast, the higher the amount to pay back, the stronger leverage the debtor state enjoys in case of default. Due to the different leverage of creditor and debtor at negotiation and in the event of default and re-negotiation, this form of external debt is particularly at odds with a Union guaranteeing equality between Member States.

This article suggests that a better understanding of European integration can be gained by juxtaposing its continuous institutionalisation and the leverage obtained by creditors from external debt relations between Member States. Both are interrelated, because institutions are on the one hand the consequence of formal negotiations or de facto bargains between states heavily influenced by debt-based power games, but on the other they also constrain options available in future discussions (Pierson, 2004). This evolution, nonetheless, features milestones or 'critical junctures' (Fioretos et al., 2016; Streeck and Thelen, 2005) that determine major changes in the playing field by switching the source of external debt that plays the most prominent role in power games. Accordingly, it is possible to identify three different constellations based on this cumulative institutionalisation of debt relations. Because of their aggregative character in European integration we shall refer to these constellations of debt relations as 'orders': since they are framed in an increasingly constrained institutional system, the relation between them is not merely chronological but also incremental. The upshot is that each of these constellations changes the ethos of European integration. As bonds tying together Member States reflect the dominating source of external debt, each order remodels the type of community resulting from integration. The article traces this evolution up to the establishment of a community of debt, as described in the last section.

\section{First-order debt relations: creditors and debtors through the balance of payments}

Regional economic integration was launched in Europe in the context of an already well-established international monetary stability guaranteed by the Bretton Woods agreements that expressed a 
radical change in purpose and strategy in international relations. In sharp contrast to the economic setting of the interwar period, commercial protectionism and competitive devaluations (the socalled 'beggar-thy-neighbour' policies) were replaced by a more collaborative and regulated environment guaranteeing a stable economic framework on a global scale and expanding the conditions for growth to developing countries (Helleiner, 2014). This spirit of co-operation took hold in the international community, but was particularly intense in Europe in the aftermath of the Second World War. This is not to deny that mistrust persisted, but to highlight that in spite of it states maintained a more co-operative disposition when engaging in new endeavours. Accordingly, the Schuman Declaration considered the 'development of the African continent' as one of the 'essential tasks' of European integration and involved the originator of two massively destructive wars in establishing 'common foundations for economic development as a first step in the federation of Europe'. Although also driven by self-interest, the inclusion of overseas territories in the European treaties (Hansen and Jonsson, 2015) and the forgiveness of Germany's debt (GalofréVilà et al., 2016) were expressions of this renewed spirit, also inspiring the constitutional refoundation of European states. With human dignity as a cornerstone, the re-born nation-states not only guaranteed a minimum level of wellbeing to all citizens through welfare policies, but accepted the shared monitoring of fundamental rights through new international instruments, setting in motion a process progressively eroding national borders. Moreover, placing the main axis of the nation-state closer to human dignity resulted in a new attitude towards neighbouring nation-states with similar political systems, to which they were open and in some cases even obliged by constitutional mandate to integrate (Fossum and Menéndez, 2011, p. 79). In sum, borders were more permeable than in previous decades. The upshot was that in post-war Europe ancient rivals, by mutually accepting supranational institutions with the ability to adopt decisions binding on all Member States, engaged in an integration project with a shared common destiny in prospect. It is on the foundations of this community of fate (Schicksalsgemeinschaft), understood as a political and institutional framework both indissolubly attaching Member States to each other while allowing for 
the resolution of conflicts between them according to internal, rule of law-based procedures (Weiler, 2017, p. 3), that the European edifice has been built up.

In accordance with this collaborative spirit and the aim of complementing - without disturbing advances in national welfare states, when designing the Treaty of Rome all parties paid careful attention to the constellation of macroeconomic relations that its entry into force would entail. The founding Member States were thus aware of the implications of external debt for their mutual relations, and accordingly crafted the provisions of economic integration in a manner that would keep debt as harmless as possible. A more problematic aspect was the imbalances that would ensue from consolidating asymmetric commercial exchanges between larger and smaller economies. Hence, the Treaty of Rome set out a compromise for each Member State to 'pursue the economic policy needed to ensure the equilibrium of its overall balance of payments' (Article 104 EEC). This was required because currencies were pegged to the dollar under the Bretton Woods regime and therefore the ability to adjust trade imbalances via the exchange rate was limited - devaluations were still possible, but only as a last resort if extreme trade deficits or surpluses jeopardized the economic stability of a country. Against this backdrop the Treaty of Rome allowed exceptional measures for the event of economic distress deriving from the establishment of the common market and the subsequent boost to cross-border trade. In accordance with the compromise to jointly address issues of common concern, the Council would resort to 'mutual assistance' in case a Member State experienced difficulties with its balance of payments. In extreme circumstances this could result in limited credit granted by other states or even in the temporary reinstatement of borders as an exception to the economic freedoms (Articles 108 and $109 \mathrm{EEC}$ ). Things were less problematic regarding the two other sources of external debt. Despite its potential negative effects, sovereign debt was not a concern for European states when signing the Treaty of Rome, not only because of the prospect of permanent growth and the ensuing ease in servicing debts, but especially because in the post-war environment of monetary stability they could issue bonds in their own currency and thus keep control over the conditions of their debt. Furthermore, due to the existence 
of capital controls investors in sovereign bonds were mostly national residents. Consequently, Member States were able to finance their policies by their own means and could avoid resorting to direct debt between them. In sum, in the monetary stability context of Bretton Woods and under the original design of the Treaty of Rome, all debt relations were embedded in a legal and institutional framework taming their negative effects.

Notwithstanding all precautions, debt-based power relations soon emerged. The Treaties were context-dependent and thus took for granted the systemic stability provided by the Bretton Woods arrangements. Although warnings about the inability of the international monetary order to deal with the scarcity of gold and with the subsequent massive use of the dollar as a reserve currency were raised early on (Triffin, 1961), the system only collapsed when one decade later the German authorities temporally ceased to support the dollar to avoid inflationary pressures and President Nixon decided to revoke the convertibility of the US dollar into gold. Currencies were forced to float against each other again, thus destabilizing a European structure carefully crafted to contain the damaging dynamics of trade in the common market. Prospects of substantial benefits by exploiting currency fluctuations dramatically increased, thus re-starting the dynamics of speculative finance. Furthermore, economic recession following restrictions in oil supply by OPEC led to global turmoil and hence to currency devaluations by many European states. In this context creditors, with the support of renewed finance, forced states to denominate new debt in foreign currency to avoid losses stemming from devaluations. Regular devaluations also affected the balance of payments between Member States, contravening the purpose of the Treaties. Consequently, direct borrowing between Member States was required in order to deal with external imbalances that were no longer automatically self-adjusted. Quite the opposite, those imbalances became permanent when capital flows were completely liberalized - a radical change in the ideological underpinnings of the 
international economic setting provoked in the late 1970 s by a unilateral decision of the United Kingdom and culminating one decade later with the adoption of a European Directive. ${ }^{1}$

The resulting constellation of power games between Member States, both during and after the Bretton Woods regime, constitutes the first order of debt relations. Under this configuration, macroeconomic relations are determined by Member States' economic power as reflected in their balance of payments in an aggregated or multilateral way that reveals a final net balance for each country - in the fashion of the European Payments Union and the subsequent European Monetary Agreement. On the basis of this zero sum game, creditors and debtors are identified in their relative positions. In the first order of debt relations, trade - among the three sources of external debt plays a dominant role due to its ability to consolidate the political influence of strong-currency countries in monetary co-operation. In particular, since no agreement can be made without their participation, these countries can display a credible exit threat from all negotiation. This asymmetry in bargaining leverage allowed them to consistently determine the rules of co-operation (Kaelberer, 2001). More specifically, the role of the Deutsche Mark as first de facto and later de jure anchor currency conferred on Germany the status of standard-setter and therefore allowed it to safeguard its domestic macroeconomic objectives, namely price stability, in every instance of monetary cooperation in European integration (Kaelberer 1997). But this meant that all other countries aiming at keeping their currency pegged to the Deutsche Mark were forced to replicate Germany's lowinflation policy. Subsequent tensions about who should bear adjustment costs led to two recurrent negotiating positions in monetary co-operation: on the one hand, the 'economist' side regarded convergence as a prerequisite for currency union, whereas on the other hand 'monetarist' views considered that convergence would result from establishment of a common currency (Dyson and Featherstone, 1999, p. 765). For the former, the burden of adjustment relied on countries catching

1 Council Directive 88/361/EEC of 24 June 1988 for the implementation of Article 67 of the Treaty (OJ L 178, 8.7.1988, pp. 5-18). 
up with the standard-setter; for the latter, the cost was to be split among all countries - the standard-setter included. The leverage of strong-currency countries explains the consistent prevalence of 'economist' views in monetary co-operation up until the collapse of communist regimes. Only then the prospect of an imminent reunification led Germany, despite its standardsetter role, to accept the establishment of an Economic and Monetary Union (EMU) before full economic convergence.

\section{Second-order debt relations: a matter of reputation}

Because of the conjunction of several historical, political and economic factors, the turn to the 1990s was a propitious moment for moving forward the European integration project. A general consensus on economic policy (McNamara, 1999) together with skilful management of negotiations on the part of the European Commission around the core idea of the internal market (Jabko, 2006) and Germany's vital interest in reunification resulted in an agreement to establish a common currency that substantially changed the nature and scope of European integration. Although the procedural path to EMU essentially followed the 'monetarist' view, launching the common currency before achieving full convergence, its constitutional design was nevertheless consistent with the interests of Germany (Kaelberer, 2001). Consequently, EMU's institutional architecture revolves around conferral of exclusive competence over monetary policy upon an independent central bank with price stability as the main objective (the European Central Bank, ECB), but keeps all other economic policies under Member States' responsibility. Fiscal policies were nonetheless co-ordinated, but especially constrained through the Stability and Growth Pact (SGP), requiring public deficit not to exceed $3 \%$ of GDP and public debt to be contained below $60 \%$ of GDP.

This setting determined the emergence of a new order of debt relations reflecting a different array of power games. This occurred as a result of the co-existence of two principles. The first makes each Member State responsible for its own economic policy. Accordingly, Eurozone states cannot assume 
financial responsibilities from any other Member State ('no bailout' provision, Article 125 TFEU) and hence the balance of payments assistance mechanisms of current Articles 143 and 144 TFEU do not apply to them. The second principle promotes the autonomy of monetary policy from politics and therefore ensures the independence of the ECB (Article 130 TFEU) and forbids central banks to financially support Member States (Article 123 TFEU). This guarantees monetary stability, in accordance with the new monetary policy paradigm (McNamara, 1999), and avoids indirect transfers between Member States, thus being consistent with the principle of state responsibility over national finances. By conferring monetary policy competences on the independent $E C B$, the Member States renounced the tools of currency devaluation and money creation to face balance-of-payments and sovereign-bond-repayment difficulties, respectively. Consequently, under EMU their financing was limited to two sources. The first is financial contributions by labour and consumption through income tax and VAT. These became critical, since the ability to tax capital and corporations was undermined by increased capital mobility and tax competition between Member States. Secondly, these limitations in tax collection and the prohibition on central bank financing of government budgets compelled Eurozone states to rely on financial markets. According to this logic, markets assess the economic performance of each Member State and establish a specific risk premium for their sovereign bonds, allegedly contributing to correcting those more reluctant to observe the fiscal discipline required by EMU (Issing, 2008, p. 18; Enderlein, 2015, pp. 19-20; cf. De Grauwe et al., 2017). The upshot is that, because of the increasing relevance of markets in financing states, in the event of a crisis, servicing debts is crucial in order to keep the confidence of creditors (Streeck, 2014, pp. 80-81). Access to markets will thus have to be ensured by any means, including budget cuts (Offe, 2015, p. 38).

This institutional design, aimed primarily at guaranteeing price stability in EMU, is in tune with the idea of a community of stability (Stabilitätsgemeinschaft) according to which the contribution of each Member State to the collective good is the stability of its own economy. Far from being an alternative to the community of fate (cf. Dyson, 2014, p. 41), the community of stability takes the 
community of fate as a precondition and adds to it a new layer of specific features. Indeed, the one even strengthens the other, since 'Europeans of both the trade surplus and the trade deficit countries are united in having a rational interest in holding fast to the Euro once they have adopted it' (Offe, 2015, p. 50). The result constitutes a new source of debt relations in which the status of creditor or debtor depends on a narrative built upon two interrelated components. The first element corresponds, as in ordinary international debt relations, to market determination of Member States' sovereign creditworthiness (Lienau, 2014, pp. 24-28; Tomz, 2007, pp. 27-28). This terminology refers to a process by which the (subjective) assessment of each country's (objective) record of debt repayments becomes consolidated and accepted as a recognizable truth. Therefore sovereign creditworthiness is no more than the concept of 'reputation' (the subjective interpretation of objective facts) adapted to the sovereign bond market. The second element results from the degree of compliance with the parameters established by the SGP. To that end the monitoring task of the Commission and public statements by the Eurogroup after its peer-review of national fiscal policies are extremely relevant. Assigning the role of creditor or debtor according to second-order debt relations thus depends on states' perceived market power according to their sovereign creditworthiness as modulated by their fiscal performance. The latter, despite the existence of a structurally sound economy at national level, is a rather open question given the number of unexpected events that affect national budgets (on both the revenue and expenditure side) and that may result in deficit or public debt increases. Therefore, in second-order debt relations assignment of the roles of creditor and debtor is based on a well-anchored and thus rather stable narrative that is nevertheless still open to changes.

The emphasis on fiscal containment for the stability of the single currency forced mixed-market economies to converge towards the export-led growth model of coordinated-market economies (Hall, 2014; Johnston and Regan, 2016). Concerns over budgetary deficit and public debt overshadowed the continuous working of first-order debt relations, still running - although inadvertently - in the background (Kaelberer, 2014). On the one hand, EMU consolidated the roles 
of creditor and debtor according to first-order debt relations, because in a currency union economies tend to specialize - saving countries develop export-led industries while consuming countries favour services - and, since the tendency to export services is weaker than exporting merchandise, surpluses and deficits become structural (Grjebine, 2015, p. 122). On the other hand, liberalization of capital made balance of payments less reliable for measuring economic power, first because current accounts were distorted by vast flows of capital no longer easily assigned to a concrete nationality and, second, because after the dismantling of administrative controls balance of payments depended on surveys rather than exact figures (Bryan, 1995, pp. 128-134). Some economists even considered balance of payments no longer a relevant goal for economic policy 'as it simply reflects greater foreign borrowing than foreign lending, arguing that there is no particular reason why the authorities should be concerned with private lending and borrowing decisions' (Østrup, 1995, p. 149). Private debt nevertheless has a destabilizing potential even for sound economies, and flows from countries with a surplus of capital to those with financial needs (creditors and debtors according to first-order debt relations) will prove destructive in EMU.

However, this was not the sole mistake regarding the operation of debt relations during these years. Although establishing a common currency avoided the risk of devaluation, market operators wrongly took for granted that in EMU the risk of insolvency was precluded - or at least negligible (Brunnermeier et al., 2016, p. 99; Kumm, 2017, p. 132). Perhaps they were only reflecting the apparent incongruity of having a common currency and an individual right to default. To be sure, for Eurozone states sovereign debt expressed in euro works as if expressed in foreign currency, since they cannot ease debt servicing by increasing the amount of money (inflation) or by devaluating the currency. In those circumstances, ruling out default exacerbates its detrimental effects in the event it finally happens. Instead, in the absence of explicit provisions regarding sovereign default in EMU, the perception of lack of risk spread and contributed to the establishment and consolidation of massive cross-border interactions between sovereigns and market actors - financial institutions in particular. 


\section{Third-order debt relations: direct debt relations between Member States}

A new set of power-based debt relations resulted precisely from the sudden and acute fear of a sovereign debt restructuring in the Eurozone. In the aftermath of the Great Recession originated by US sub-prime mortgages, this eventuality was considered extremely damaging for still-vulnerable financial institutions all across Europe. The close interrelation, if not symbiosis, between an overly inflated financial sector and local, regional and national public authorities (Kumm, 2017) obliged European leaders to be extremely cautious in order to avoid private losses that could subsequently affect public finances; hence their aversion, during the severest stage of the crisis, to accepting any kind of default in the Eurozone that could distress their own financial institutions. The ensuing conflict between circumstantial politico-economic needs (guaranteeing debt repayment) and sovereign prerogatives (the right to default has not been conferred on the EU and thus, according to Articles 4.1 and 5.2 TEU, remains exclusively a national competence) was resolved through a common agreement between European leaders that ultimately unleashed new power games defining third-order debt relations. This compromise resulted from the very specific context of the Greek sovereign debt crisis and had Germany as its main opponent. Although initially reluctant to disregard EMU foundations and thus prone in principle to supporting debt restructuring as an expression of national fiscal responsibility (cf. Offe, 2015, p. 46), the fear of being presented as mainly responsible for whatever subsequent (and eventually dramatic) economic consequences (Sandbu, 2017, pp. 57-58) led Germany to finally accept the majority opinion among European leaders, namely to financially assist Greece once it was unable in May 2010, after several months of mounting tension, to refinance its debt in financial markets. This was possible only as a last resort (meanwhile aggravating the assessment of Greek sovereign debt) and under strict conditionality which ensured, first, that financial aid could be considered compatible with the non-bailout principle 
of Article 125 TFEU (as the Court of Justice finally ruled in Pringle) ${ }^{2}$ and, second, that reforms deemed unavoidable were not postponed, thus preventing subsequent financial transfers in the long run (Sandbu, 2017, p. 59).

The actual trigger for the configuration of third-order debt relations was the signature of a Memorandum of Understanding (MoU) by Greece expressing concrete economic and political reforms to be adopted in the short and medium term as consideration for the financial assistance provided by its counterparts. Third-order debt relations are thus an expression of political power, revealed in the details of the MoU and the Loan Agreement (for the Greek case see Skiadas, 2013, pp. 90-91) as well as in the procedure granting financial aid in successive tranches, namely only after confirmation of compliance with conditions attached to the previous tranche - compliance to be determined by creditors themselves. Moreover, by imposing the specific policy choices of creditors, these agreements disavow a debtor's authorities and democratically elected institutions, ultimately undermining the representativeness of its democratic system (Crum, 2013). It is worth noting that in this relationship debtors are singled out, thus diminishing their bargaining options against a conglomerate of creditors. In this regard, it has been asked why, at the peak of the sovereign debt crisis, debtor countries - aiming to change the narrative of the response to the crisis and its corresponding power game - did not claim that together they represented a systemic risk for the stability of the EU - a claim that proved so effective with banks (Offe, 2015, p. 53). The general answer, valid for international debt relations, is that co-operation leading to the formation of a cluster or cartel of debtors is hindered by the wide variation in their size and total debt burden (Aggarwal, 1987, p. 32). A more concrete explanation, specific for EMU, is that in a community of stability those jeopardizing the common good of shared stability are identified and blamed for it. It is thus not surprising that countries in severe financial difficulty, and thus in need to reassure oversensitive financial markets about their sovereign creditworthiness, were interested in

\footnotetext{
2 C-370/12, Pringle, EU:C:2012:756, paragraph 143.
} 
differentiating themselves from those perceived as profligate states rather than in forming a coalition with them. In this regard, the community of stability proved feasible during economic expansion, but more problematic at times of crisis (Beck, 2013, p. 10).

Although in the context of the Great Recession financial aid had previously been conceded to some non-Eurozone states, ${ }^{3}$ the decision by the European Council to grant financial assistance to Greece under a strict set of economic policy conditions reflecting Germany's ideational power (Matthijs and McNamara, 2015) marked a turning point in European integration. This decision not only unleashed the sovereign debt crisis but also established a new framework for relations between Eurozone Member States that can be described as a community of debt (Schuldengemeinschaft) according to which members of the Eurozone cannot default and are instead forced to borrow money from other Eurozone Member States, thus engaging in direct debt relations that somehow paradoxically tear creditors and debtors apart while bonding them together (Beck, 2013, Ch. 1). Consequently, thirdorder debt relations establish actual, direct and concrete creditor-debtor relations between Eurozone States - the kind of external debt that, by definition, was supposed to be less compatible with European integration because although in principle both creditor and debtor Member State(s) are interested in the success of their transaction, as soon as a shadow of default is cast mistrust replaces confidence and avoidance of losses gains priority. The confrontational dynamics inherent to this type of external debt spread almost immediately throughout the EU and reshaped its very foundations: mutual trust was immediately transmuted into a latent mistrust that became engrained in all institutional developments. A major illustration of this transformation resides in the de facto abolition of the principle of equality between Member States, enshrined in Article 4.2 TEU, as a result of new power games that pervaded the institutional system (Losada, 2016), thus rearranging 3 Hungary, Latvia and Romania benefited from application of the programme assisting non-Euro Member States experiencing difficulties in their balance of payments, established under Article 143 TFEU by Council Regulation (EC) 332/2002, of 18 February 2002, establishing a facility providing medium-term financial assistance for Member States' balances of payments (OJ L 53, of 23.02.2002, pp. 1-3). 
the logic of integration from consensus to domination (Fabbrini, 2016). This is most visible in the workings of such informal institutions as the Eurogroup or the Eurosummit, where the interests of creditors and debtors are openly in conflict. In particular, a decision to grant financial assistance or to disburse a successive tranche of aid to a given country is susceptible to fall under the dynamics of new power games because of the weak position of the debtor, unable to negotiate with creditors once deprived of the option of default. This explains why, in a dynamic close to that of blackmail, acceptance of the terms of the agreement on the part of creditors is subject to acceptance by the debtor of issues barely related to the subject matter. ${ }^{4}$ The effects of the confrontational dynamics of direct debt relations also reached the judicial structure of the Union, where power asymmetries adopt the legal form of double standards (Joerges, 2016, p. 326). The impact of the antagonistic logic of direct debt relations, now installed in the EU, persisted even when Greece was allowed to partially default: instead of the Greeks, negotiations with third parties were conducted by the French and German authorities (Skiadas, 2013, p. 142). These practices express a change in the rationale of European integration. Accordingly, the priorities of public authorities in a community of debt include not only to guarantee debt-servicing to financial markets in order to keep sovereign creditworthiness at a reasonable rate - an aim contributed to by the principle of budgetary stability nowadays enshrined in the national legal orders of almost all EU Member States due to the signature of the Treaty on Stability, Coordination and Governance in EMU - but especially to fully repay all debts owed to the other members of the Union. This changing rationale has its institutional

4 By way of illustration, Spain threatened Greece with vetoing the next disbursement of the financial assistance programme unless judicial immunity was granted to a Spanish civil servant, charged together with an Italian, a Slovenian and three Greeks with crimes of bad faith when advising Greece in the sale and subsequent lease of 28 public facilities. El País, "España amenaza con vetar el rescate a Grecia por un conflicto judicial", $17^{\text {th }}$ June $2017, \quad$ available https://elpais.com/internacional/2017/06/16/actualidad/1497596431 472840.html (last visited on 07.06.2018). 
reflection in the amendment of Article 136.3 TFEU, which subjects financial assistance to strict conditionality. Hence, common institutions are now in charge of guaranteeing debt repayment when they are not creditors themselves. Accordingly, conditionality inspires the concrete requirements demanded by the European Stability Mechanism (ESM) when disbursing financial aid and by the ECB if it is to implement its OMT program.

\section{The emerging European community of debt: Implications and conclusions}

The three different orders of debt relations just described reflect the transformation of the European Union from a community of fate to a community of stability, and from there to the current community of debt. These three different constellations have not simply succeeded each other in time. The relationship between the three is rather incremental, in the sense that each of them has shaped its successor. Thus, the community of stability departs from the community of fate, whose shared goal is to build 'an ever closer Union among the peoples of Europe', as declared in the preamble to the EEC Treaty. Creation of monetary union was a step forward in that direction, which required budgetary discipline at national level. Once that community of stability was established (the German Constitutional Court even linked the legality of the German ratification of the Maastricht Treaty to EMU being conceived as such $)^{5}$ and Member States were subjected 'to the logic of the market when they enter into debt', ${ }^{6}$ any step backwards will be perceived as endangering the community of fate itself. Therefore, compulsory and integral redemption of debts instead of defaulting at the expense of the other members of the community comes to be seen as of the essence (Steinbach, 2016). As a consequence of this evolution, the implications of a given event are radically different depending on the institutional context in which it takes place. Hence, while in the

5 German Constitutional Court, Manfred Brunner and Others v. The European Union Treaty (Cases 2 BvR 2134/92 \& 2159/92), [1994] 1 C.M.L.R. 57, paragraph 90.

6 Judgment in Pringle EU:C:2012:756, paragraph 135.

This article is protected by copyright. All rights reserved. 
community of fate financial assistance through the mechanism stipulated in Articles 108 and 109 of the EEC Treaty was an expression of solidarity, under the community of debt what lies behind loans granted by the several vehicles and institutions created to that end is a clash of interests between the signatories of the MoU. Moreover, despite being coetaneous, financial assistance to nonEurozone members and to Greece involved radically different consequences: because of the diverse institutional setting in which they took place, only the latter meant the move from second to third order debt relations.

The transition from a community of fate to the current community of debt implies a set of changes in the elements configuring each order of debt relations that can be sketched along three converging trends: (1) the individuation of debtor states; (2) the increasingly explicit character of the leverage gained by creditor states; (3) the narrowing down of the geographical scope of each constellation (see Table 1). Accordingly, first-order debt relations are an expression of economic power as measured by the aggregated (intra-Community) balance of payments. The status of debtor is therefore fundamentally based on objective criteria (performance of the economy) and depends on a relative positioning in which both creditors and debtors are identified. In second-order debt relations, assigning these roles depends on financial markets' assessment of national sovereign creditworthiness (particularly important for members of the Eurozone), as modulated by the fiscal performance of states. The clear limits established in the SGP define what is considered behaviour beyond normal standards, thus reprehensible via peer pressure in the Eurogroup and suitable for sanctioning either indirectly (by public naming, thereby hampering access to markets) or, if breach of the rules is persistent, directly by the Council following a recommendation from the Commission (Sections 8,9 and 11 of Article 126 TFEU). Here, instead of being based on a relative position, assignment of the roles of creditor and debtor results from identifying deviant behaviour: debtors are singled out while creditors are simply those behaving according to the rules. Finally, third-order debt relations assign the role of debtor depending on the signature of a MoU by which financial assistance is provided under strict conditionality to a Eurozone state in order to address some 
particular financial problem. Regardless of where the latter stems from (fiscal policy, the private sector or a combination of both), power relations will emerge in the form of a concrete political programme imposed on the debtor state. All trends seem thus to converge towards singling out debtor states in the Eurozone - states which are fully responsible for their public and private debts, as required by a community of debt.

\section{TABLE 1 AROUND HERE}

On the other hand, creditors have recurrently obtained advantages from all instances of monetary co-operation. Under first-order debt relations they benefited from specific asymmetries inherent to pegged exchange-rate systems (Kaelberer, 1997), from which they obtained increased leverage in macroeconomic negotiations. The agreement on EMU, at the origin of second-order debt relations, consequently reflected concrete demands by creditors regarding the single monetary policy objective (price stability) and the independent status of the responsible institution (ECB), since then both enshrined in the Treaties. National responsibility over fiscal policy, avoiding all redistribution and transfer of resources at European level, was a core element of the constitutional design of EMU, too. Crucially, the rules of the SGP conveniently focused on deficits but not on surpluses, thus imposing the costs of adjustment on debtors. Once unexpected events led to third-order debt relations, changing the rationale of integration, all the measures adopted followed the ideational power of Germany and made asymmetric adjustment even more pronounced. Creditors' interests became nested in the EU institutional system and surplus imbalances conveniently overlooked (Dyson, 2014, p. 616).

The narrative proposed in this article, relying on the reconstruction of European integration according to three different orders of debt relations, helps to identify and coherently articulate key events and developments determining not only the structure but also the substance of integration. For instance, it sheds light on the increasing relevance of conditionality as governance mechanism in European integration during the last decade - to the point of currently being well entrenched into 
EU law (Viţă, 2017). But in particular it is capable of illuminating the ultimate reason behind EU postcrisis legal and political conflicts: imbalances and asymmetries inherent to macroeconomic integration are in conflict with the rule of law, whose core premise is equality between all parties. This contradiction explains both the malfunction of rule-based macroeconomic integration and the subsequent lack of legitimation of the measures adopted once the rationale of integration changed and EU law was oriented to guaranteeing full repayment of debts. The scrutiny of European integration from the perspective of debt relations thus gives room for much-needed new paradigms capable of combining in the same account a consistent explanation of the historical process of integration with the specifics of the post-crisis political regime (Joerges and Kreuder-Sonnen, 2017, p. 137). This article constitutes but a first attempt in this regard and as such it will be complemented by and tested against further research.

\section{References}

Aggarwal, V. K. (1987) 'International Debt Threat: Bargaining among Creditors and Debtors in the 1980s'. Institute of International Studies (University of California - Berkeley), Policy Papers in International Affairs, No. 29.

Beck, U. (2013) German Europe (Cambridge: Polity Press).

Brunnermeier, M. K., James, H. and Landau, J.-P. (2016) The Euro and the Battle of Ideas (Princeton and Oxford: Princeton University Press).

Bryan, D. (1995) The Chase Across the Globe: International Accumulation and the Contradictions for the Nation States (Boulder: Westview Press).

Crum, B. (2013) 'Saving the Euro at the Cost of Democracy?'. Journal of Common Market Studies, Vol. 51, No. 4, pp. 614-630.

De Grauwe, P., Ji, Y. and Steinbach, A. (2017) 'The EU Debt Crisis: Testing and Revisiting Conventional Legal Doctrine'. International Review of Law and Economics, Vol. 51, pp. 29-37. 
Dyson, K. and Featherston K. (1999) The Road to Maastricht: Negotiating Economic and Monetary Union (Oxford: Oxford University Press).

Dyson, K. (2010) 'Norman's Lament: The Greek and Euro Area Crisis in Historical Perspective'. New Political Economy, Vol. 15, No. 4, pp. 597-608.

Dyson, K. (2014) States, Debt, and Power: 'Saints' and 'Sinners' in European History and Integration (Oxford: Oxford University Press).

Enderlein, H. (2015) 'Towards an Ever Closer Economic and Monetary Union?'. In Dawson, M., Enderlein, H. and Joerges, Ch. (eds) Beyond the Crisis: The Governance of Europe's Economic, Political, and Legal Transformation (Oxford: Oxford University Press), pp. 13-23.

Fabbrini, F. (2015) 'States' Equality v States' Power: the Euro-crisis, Inter-state Relations and the Paradox of Domination'. Cambridge Yearbook of European Legal Studies, Vol. 17, pp. 3-35.

Fabbrini, S. (2016) 'From Consensus to Domination: The Intergovernmental Union in a Crisis Situation'. Journal of European Integration, Vol. 38, No. 5, pp. 587-599.

Fioretos, O., Falleti, T. and Sheingate, A. (eds.) (2016) The Oxford Handbook of Historical Institutionalism (Oxford: Oxford University Press).

Fossum, J. E. and Menéndez, A. J. (2011) The Constitution's Gift: A Constitutional Theory for a Democratic European Union (Lanham: Rowman and Littlefield).

Galofré-Vilà, G., McKee, M., Meissner Ch. M. and Stuckler, D. (2016) 'The Economic Consequences of the 1953 London Debt Agreement'. NBER Working Paper, No. 22557.

Grjebine, A. (2015) La dette publique et comment s'en débarrasser: Désendetter les États européens sans compromettre la croissance, c'est possible! (Paris: Presses Universitaires de France).

Hall, P. A. (2014) 'Varieties of Capitalism and the Euro Crisis'. West European Politics, Vol. 37, No. 6, pp. $1223-1243$.

Hannesson, R. (2015) Debt, Democracy, and the Welfare State: Are Modern Democracies Living on Borrowed Time and Money? (Basingstoke: Palgrave). 
Hansen, P. and Jonsson, S. (2015) Eurafrica: The Untold History of European Integration and Colonialism (London: Bloomsbury).

Helleiner, E. (2014) Forgotten Foundations of Bretton Woods: International Development and the Making of the Postwar Order (Ithaca and London: Cornell University Press).

Hirschman, A. O. (1945) National Power and the Structure of Foreign Trade (Berkeley: University of California Press).

Issing, O. (2008) The Birth of the Euro (Cambridge: Cambridge University Press).

Jabko, N. (2006) Playing the Market: A Political Strategy for Uniting Europe, 1985-2005 (Ithaca: Cornell University Press).

Joerges, Ch. (2016) 'Integration through Law and the Crisis of Law in Europe's Emergency'. In Chalmers, D., Jachtenfuchs, M. and Joerges, Ch. (eds) The End of the Eurocrats' Dream: Adjusting to European Diversity (Cambridge, Cambridge University Press), pp. 299-338.

Joerges, Ch. and Kreuder-Sonnen, Ch. (2017) 'European Studies and the European Crisis: Legal and Political Science Between Critique and Complacency'. European Law Journal, Vol. 23, No. 1-2, pp. $118-139$.

Johnston, A. and Regan, A. (2016) 'European Monetary Integration and the Incompatibility of National Varieties of Capitalism'. Journal of Common Market Studies, Vol. 54, No. 2, pp. 318-336. Kaelberer, M. (1997) ‘Hegemony, Dominance or Leadership? Explaining Germany’s Role in European Monetary Cooperation'. European Journal of International Relations, Vol. 3, No. 1, pp. 35-60.

Kaelberer, M. (2001) Money and Power in Europe: The Political Economy of European Monetary Cooperation (Albany: State University of New York Press).

Kaelberer, M. (2014) 'Sovereign Debt or Balance of Payments Crisis? Exploring the Logic of Adjustment in the Eurozone'. Journal of Balkan and Near Eastern Studies, Vol. 16, No. 4, pp. 419436.

Kirshner, J. (2006) 'Currency and Coercion in the Twenty-First Century'. In Andrews, D. M. (ed) International Monetary Power (Ithaca: Cornell University Press), pp. 139-161.

This article is protected by copyright. All rights reserved. 
Kumm, M. (2017) 'Causes of the Financial Crisis and Causes of Citizen Resentment in Europe: What Law has to do with It'. In Papadopoulou, L., Pernice, I. and Weiler, J. H. H. (eds) Legitimacy Issues of the European Union in the Face of Crisis (Baden-Baden: Nomos), pp. 129-148.

Lienau, O. (2014) Rethinking Sovereign Debt: Politics, Reputation and Legitimacy in Modern Finance (Cambridge: Harvard University Press).

Losada, F. (2016) 'Institutional Implications of the Rise of a Debt-Based Monetary Regime in Europe'. European Law Journal, Vol. 22, No. 6, pp. 822-837.

Matthijs, M. and McNamara, K. (2015) 'The Euro Crisis' Theory Effect: Northern Saints, Southern Sinners, and the Demise of the Eurobond'. Journal of European Integration, Vol. 37, No. 2, pp. 229-245.

McNamara, K. (1999) The Currency of Ideas: Monetary Politics in the European Union (Ithaca: Cornell University Press).

Offe, C. (2015) Europe Entrapped (Cambridge: Polity Press).

Østrup, F. (1995) 'Economic and Monetary Union'. In Laursen, F. (ed) The Political Economy of European Integration (The Hague: Kluwer Law International), pp. 145-176.

Pierson, P. (1998) 'The Path to European Integration: A Historical Institutionalist Analysis'. In Sandholtz, W. and Stone-Sweet, A. (eds) European Integration and Supranational Governance (Oxford: Oxford University Press), pp. 27-58.

Pierson, P. (2004) Politics in Time: History, Institutions and Social Analysis (Princeton: Princeton University Press).

Pierson, P. (2015) 'Power and path dependence'. In Mahoney, J. and Thelen, K. (eds) Advances in Comparative-Historical Analysis (Cambridge: Cambridge University Press), pp. 123-146.

Sandbu, M. (2017) Europe's Orphan: The Future of the Euro and the Politics of Debt (Princeton and Oxford: Princeton University Press).

This article is protected by copyright. All rights reserved. 
Skiadas, D. V. (2013) 'Tackling Greece’s Financial Crisis: A Legal-Institutional Viewpoint'. In Lavdas, K. A., Litsas, S. N. and Skiadas, D. V., Stateness and Sovereign Debt: Greece in the European Conundrum (Lanham: Lexington Books).

Steinbach, A. (2016) 'The "haircut" of public creditors under EU law'. European Constitutional Law Review, Vol. 12, No. 2, pp. 223-239.

Steinberg, F. and Vermeiren, M. (2016) 'Germany's Institutional Power and the EMU Regime after the Crisis: Towards a Germanized Euro Area?'. Journal of Common Market Studies, Vol. 54, No. 2, pp. $388-407$.

Streeck, W. and Thelen, K. (2005) 'Introduction: Institutional Change in Advanced Political Economies'. In Streeck, W. and Thelen, K. (eds) Beyond Continuity: Institutional Change in Advanced Political Economies (Oxford: Oxford University Press), pp. 1-39.

Streeck, W. (2014) Buying Time: The Delayed Crisis of Democratic Capitalism (London and New York: Verso).

Tomz, M. (2007) Reputation and International Cooperation: Sovereign Debt across Three Centuries (Princeton: Princeton University Press).

Triffin, R. (1961) Gold and the Dollar Crisis: The Future of Convertibility (New Haven: Yale University Press).

Viţă, V. (2017) 'Revisiting the Dominant Discourse on Conditionality in the EU: The Case of EU Spending Conditionality'. Cambridge Yearbook of European Legal Studies, Vol. 19, pp. 116-143.

Weiler, J. H. H: (2017) 'Editorial: The Case for a Kinder, Gentler Brexit'. International Journal of Constitutional Law, Vol. 15, No. 1, pp. 1-8. 